\title{
Review of the Survey's activities in 1983
}

\section{K. Ellitsgaard-Rasmussen}

\section{Director}

In recent years there has been an increase in interest in the development of hydropower in the vicinity of the towns in Greenland. To meet this commitment GGU has had to expand its glaciological activity. Since existing knowledge of hydrological basins is insufficient to meet all the new requests, mass balance studies have been started at two additional glaciers - Buksefjord $\left(64^{\circ}\right)$, and Pâkitsup ilordlia $\left(69^{\circ}\right)$ north of Jakobshavn. The existing projects at Johan Dahl Land in South Greenland and Qamanârssûp sermia at the head of Godthåbsfjord are now in their fifth and third years of study, respectively. Landsat images have been used to help define basin sectors on the Inland Ice where the ice sheet forms lobes used in basin analyses. On a local basin in the region of Jakobshavn Isbræ a series of stakes has been set out extending from the edge of the Inland Ice to as far as $80 \mathrm{~km}$ inland, and up to an altitude of $1500 \mathrm{~m}$ above sea level.

The ARCO/Nordisk Mineselskab consortium was granted permission in 1982 by the Ministry for Greenland to carry out a seismic test programme in three pre-selected areas of Jameson Land, central East Greenland. GGU was involved in this programme in a supervising control function on behalf of the Danish State. In addition, the Section for Oil Geology of the Survey carried out its own oil geological programme in the Jameson Land area. Sampling of possible source rocks was made with the aid of a portable drill. In particular the Upper Permian deposits were selected for detailed work as they are considered to contain the most promising part of the Jameson Land sequence with respect to content of source rocks and to some extent also reservoir rocks. The drilling programme was supplemented by studies of the Late Palaeozoic basin configuration, tectonics and sediment types.

The programme of mineral resources mapping and evaluation was continued in central West Greenland. In 1982 this programme included the detailed collection of material in connection with known sulphide mineralisation in a sequence of norite intrusions east of Sukkertoppen. A geomagnetic and geoelectric survey was carried out in the same region. Soil samples were collected over a sulphide mineralisation of the 'Fossilik' norite body, and a geochemical programme was carried out in the eastern part of Sukkertoppen district. The supracrustal rocks south of Godthåbsfjord were also a subject of study, in the course of which it was established that chalcopyrite and molybdenite are more widespread than previously recognised. Areas with scheelite mineralisation were also recognised in the area.

The 1:100000 mapping programme in the inner part of Godthåbsfjord con- 


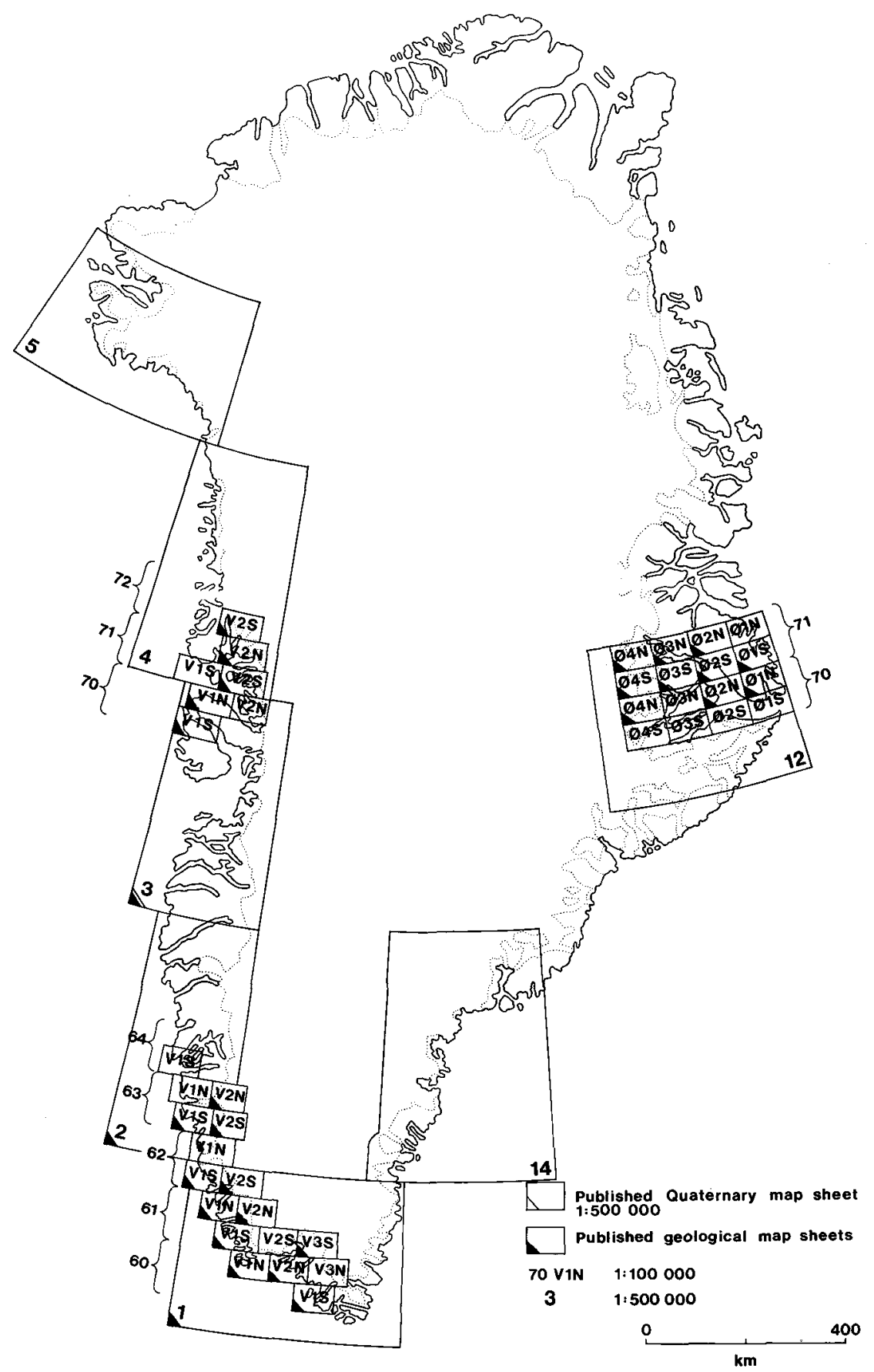

Fig. 2. Map sheets published and in preparation by the Survey (see inside rear cover). 
tinued according to plan with operations from the GGU base camp at Kangiussaq. Work was concentrated on the two map sheets Isukasia (65 V.2 S) and Ivisârtoq (64 V.2 N), the latter under contract to a group from Exeter University (England). The field work on the Isukasia sheet was completed.

The group working on the 1:500 000 regional mapping between Angmagssalik and Tingmiarmiut had to concentrate their work around Tingmiarmiut, as ice conditions were extremely difficult and prevented them reaching further north.

The Survey plans to continue field activity in North Greenland in 1984 and 1985. In connection with the logistics planning for this activity, visits were made to Thule Air Base and the USA/Canadian air base at Alert on Ellesmere Island (Canada), of which the latter will act as the main base because of its close proximity to the western part of North Greenland. A site for a possible subsidiary base was examined on Warming Land.

The Syduran reconnaissance project for uranium in South Greenland came to an end in 1981. However, it was extended with funding from The Energy Agency in order to clarify the causes of the various uranium anomalies located in the reconnaissance phase of the project, and establish if they represent mineralisation with some economic potential. The areas to be studied in more detail include the Igaliko peninsula, Nordre Sermilik, the Motzfeldt intrusion, and Lindenows Fjord to Kap Farvel on the east and south coasts. Local geomagnetic and electromagnetic surveys were carried out in connection with the mapping of the mineralised joint and fault system.

The major programme (NAD) for the mapping of the offshore area of East Greenland together with Denmark Strait was continued in 1982 with the completion of the marine geophysical survey. In the final season $2798 \mathrm{~km}$ of line profile data were collected on behalf of the Survey by Western Geophysics Company of America operating with the vessel Western Arctic. The information accumulated this summer included gravimetric, magnetic and reflection seismic data. This programme is funded jointly by the EEC (75\%) and The Energy Agency (25\%) as part of energy research programmes.

The remote sensing project was essentially completed in 1981, but lacked a field season on the ground to check the results arrived at. This ground check was completed during the summer as an extension of the original project.

The regional programme of radiometric age dating was continued during the year, one field party making a collecting trip between Holsteinsborg and Upernavik.

In connection with a proposal by Kryolitselskabet Øresund A/S to reopen the cryolite mine at Ivigtut to extract the remaining low-grade cryolite, the water and fauna in the fjord outside the old open pit were sampled and analysed to determine the local level of a number of heavy elements. The mine was last worked in 1962, though cryolite has been shipped from stock piles since then. Routine visits were also made to the fjord region adjacent to the lead-zinc mine at Mârmorilik, as part 
of the monitoring of the environmental impact of the mining activity. The Survey was also involved in an inspection function in connection with the exploration activities by Kryolitselskabet Øresund A/S at Atâ (Arveprinsens Ejland), north of Jakobshavn, and on the Akuliaruseq peninsula (Nordre Strømfjord), south of Egedesminde, in central West Greenland. 